\title{
19: 45483036-45431556
}

National Cancer Institute

\section{Source}

National Cancer Institute. 19: 45483036-45431556. NCI Thesaurus. Code C41679.

Physical location of AKT2_Gene 